\title{
Floral Diversity Status in Urban Coastal Wetland \& Associated Coastal Ecosystems of Crow Island Mattakkuliya, Sri Lanka
}

\author{
Nisitha Yapa*, Kasunthi Amarasekara, Shamali Rathnasri \\ Department of Coastal and Marine Resources Management, Faculty of Engineering and Management, Ocean University of Sri \\ Lanka, Colombo 15, Sri Lanka \\ Email: *nisithayapa@gmail.com
}

How to cite this paper: Yapa, N., Amarasekara, K. and Rathnasri, S. (2022) Floral Diversity Status in Urban Coastal Wetland \& Associated Coastal Ecosystems of Crow Island Mattakkuliya, Sri Lanka. Open Journal of Ecology, 12, 51-65.

https://doi.org/10.4236/oje.2022.121003

Received: December 14, 2021

Accepted: January 17, 2022

Published: January 20, 2022

Copyright $\odot 2022$ by author(s) and Scientific Research Publishing Inc. This work is licensed under the Creative Commons Attribution International License (CC BY 4.0).

http://creativecommons.org/licenses/by/4.0/

\begin{abstract}
Colombo is the capital of Sri Lanka and the only wetland city in South Asia under the Ramsar Convention. Crow Island Beach Park and associated coastal area belong to the Colombo urban coastal wetland ecosystems. Crow Island wetland contributes diverse habitats for numerous flora and fauna species. The present study was conducted to assess the status of floral diversity in the Crow Island Beach Park and associated coastal ecosystem during the months of August to October 2021. Study area is divided in to three sites (A, B, C). Line transects method and field observations were used in the study. This coastal wetland consists of mosaic of five major vegetation types: Herbaceous, tree, shrub, creeper, grass and other than that marine algae namely Chaetomorpha antennina, Rhizoclonium africanum, Ulva compressa belonging to chlorophyta (green algae) and Grateloupia lithophila belonging to rhodophyta (red algae) were found in the study area. A total number of 102 flora species belonging to 50 families were recorded from the study area. There were two true mangrove species and 16 mangrove associated species in the study sites. Out of the 102 plant species 46 were recognized and documented as plants with medicinal values. Shannon-Wiener diversity indexes for mangrove and mangrove associated species were recorded as 2.378, 2.304 and 1.676 in site A, B and $\mathrm{C}$ respectively. Simpson's diversity index for mangrove and mangrove associated species was recorded as $0.889,0.874$ and 0.735 respectively in site A, B and C and Jaccard index of similarity between three study sites showed high values ranging from $41 \%$ to $69 \%$ for mangrove and mangrove associated species.
\end{abstract}

\section{Keywords}

Beach Park, Coastal Ecosystem, Floral Diversity, Seaweeds, Urban Wetland, Mangrove 


\section{Introduction}

Sri Lanka has a diverse range of coastal habitats that include estuaries and lagoons (214,522 ha), mangroves (11,656 ha), seagrassbeds (37,137 ha) salt marshes (27,520 ha), coral reefs (not determined) and large extents of beaches including barrier beaches [1]. Each of these coastal habitats possesses a significant amount of species and provides an array of ecosystem services vital to human. In addition to the environmental services, these habitats support livelihoods of the coastal communities in significant manner to enhance their economic status and maintain social integrity [2]. Sri Lankan coastline is approximately $1585 \mathrm{~km}$ [1]. Coastal habitats comprise a rich component of the country's coastal and marine biodiversity. Genetic diversity within coastal habitats is also believed to be high with a possible economic value [1]. The non-extractive value of coastal habitats such as coral reefs, mangroves, estuaries/lagoons and beaches, is very high with the ecosystem services they provide. The water bodies of lagoon and estuaries function like buffer zones, protect coastal communities from full force of weather related events, such as storm surges, floods and cyclones by damping wave action, dissipating river discharge and temporarily storing water. The habitats such as mangroves, sea grass beds and salt marshes function as large filters to extract pollutants, excess nutrients and sediment carried out from municipal and industrial wastewater inland and storm water runoff [3]. Although mangroves occur on saline soils, they have the usual plant requirement of freshwater, nutrients and oxygen. Mangrove area represents a small percent of Sri Lanka's total low energy coastal habitat [4]. The width of mangrove forest depends on the tidal amplitude (5) and in Sri Lanka where tidal amplitude is very low $(75 \mathrm{~cm})$ [5], mangroves are usually limited to rather narrow belts. The major mangroves in Sri Lanka are located around Jaffna, Wadamarchchi, Thondamanar lagoons Kokilai, Navaru, Trincomalee, Kathiraveli, Valaichcenai, Batticaloa, Pothuvil, Weligama, Gintota, Balapitiya, Bentota, Negombo, Chilawlagoon, Puttalamlagoon, Mannar [6]. Mangroves in Sri Lanka have been discontinuously distributed along the coast around lagoons, bays and estuaries covering an area between $8000-$ 7000 hectares [7]. However a recent estimate showed that the extent of mangroves in Sri Lanka is about 15,670 hectares [8]. Although records on the true Mangrove species from Sri Lanka are inconsistent, occurrence of 21 species of mangroves [9] is widely accepted now. The region is very narrow and extends only $300 \mathrm{~m}$ along the stretch of the country Beach flora such as Pandanus odorifer, Barringtonia asiatica, Ipomoea pes-caprae, Scaevola taccada and Scaevola plumieri can be identified [1]. Wetlands are habitats with permanent or temporary accumulation of water with associated floral and faunal communities.

Colombo is the capital of Sri Lanka and it is also south Asia's only Wetland City under the Ramsar Convention since 2018 [10]. The Crow Island beach park is situated in the Coastal boundary in Mattakkuliya, Colombo North. The Crow Island and associated area belongs to the coastal plain and the flood plain of the Kelani River [11]. Therefore, much of the area is less than five meters above sea 
level. The physiography can be described in terms of its dominant landscape units according to their possible origin. At least three such units could be identified in the immediate environs of Crow Island namely, coastal, fluvial and denudation [12]. Wetlands comprise of a combination of soils, water, plants and animals. The interplay between these elements allows wetlands to perform several functions that are beneficial to humankind, while generating healthy wildlife, fisheries and forest resources. The combination of these functions, together with the rich biological diversity and cultural heritage of wetlands makes these ecosystems invaluable to people all over the world [12]. The majority of the land in crow island study area is flat land with sandy beach distributed along the west coastal band, and there is a small lagoon at the southern corner with associated mangrove vegetation which is fed by the Crow Island canal started from Kelani river. The Crow Island beach is a certain land section with high aesthetic natural excellence. Numerous birds and plant species are associated with coastal vegetation and the mangrove patch that gives a higher ecological value and a scenic beauty to the area. Preliminary study of the avifaunal diversity of Crow Island Beach Park revealed that this coastal wetland is a suitable habitat for variety of birds including water birds [13]. Therefore Crow Island Beach Park and associated area is comprised of high faunal and floral diversity. This might be due to different type of habitats in one place as well as availability of food and shelter in the area [13]. Various studies on floral and faunal diversity of wetlands in Sri Lanka have been conducted by different authors however very few studies have done so far for this Beach Park which is coming under the Colombo Ramsar Wetland City. Conversely as a result of not having formal extension and management mechanism in the beach park area this floral diversity and the other resources are being misused and ecological quality is degrading day by day. Therefore Floristic inventories and diversity assessments are necessary to understand the present diversity status and conservation of this coastal wetland ecosystem.

\section{Methodology}

The study was conducted at the Crow Island Beach Park and associated wetland area in western province $\left(6^{\circ} 58^{\prime} 24.1^{\prime \prime} \mathrm{N}, 79^{\circ} 52^{\prime} 09.9^{\prime \prime} \mathrm{E}\right)$ of Colombo 15 , during the months of August to October. The overall study area's land extends approximately 15 hectares. Study area was divided into three major areas for sampling purposes.

The site A (Figure 1) is identified as Crow Island Beach Park situated in the coastal boundary in Mattakkuliya, Colombo North. The area is owned and managed by the Colombo Municipal Council. Boundaries of this landscape are, naval base and NARA (National Aquatic Resources Research and Development Agency) premises (North), small lagoon (South), domestic and commercial area (East), sea (Western). Site B (Figure 1) is identified as a small lagoon associated area located in the backyard of NARA premises. Boundaries are, small canal that 


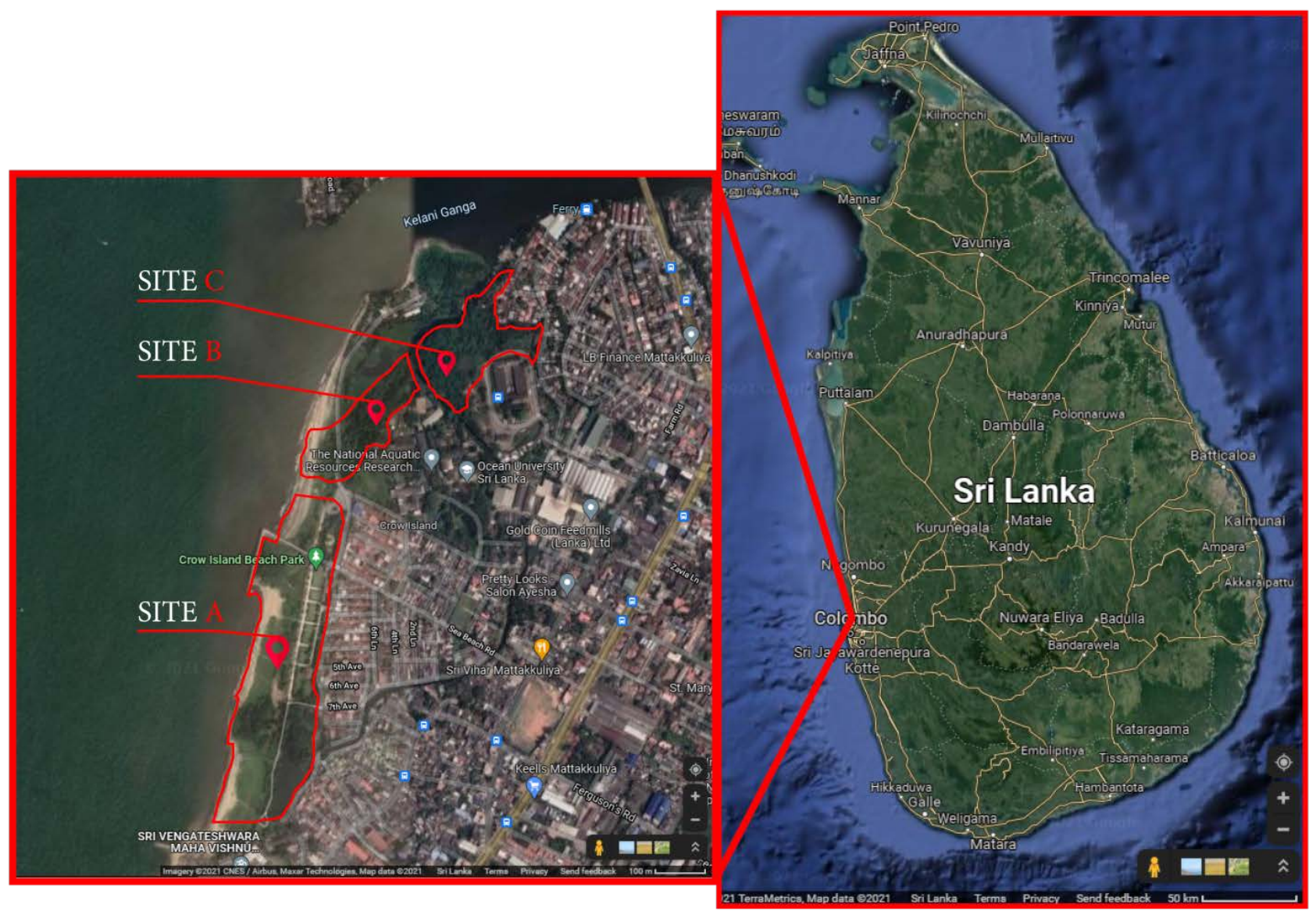

Figure 1. Satellite image of the study area $\left(6^{\circ} 58^{\prime} 24.1^{\prime \prime} \mathrm{N}, 79^{\circ} 52^{\prime} 09.9^{\prime \prime} \mathrm{E}\right)$ source Google Map.

start from Kelani River (North), sea beach road, Crow Island (South), backyard area of NARA premises and water logged small canal (East), lagoon area (Western). This area is owned and managed by NARA. Site C (Figure 1) is identified as periodically inundated low land area. This land area is owned and managed by National Aquatic Resources and Research Development Authority. Boundaries are, neighboring houses (North), canal that started from Kelani river lagoon (South), Sri Lanka Transport Board Mattakkuliya Depot premises (East), lagoon area (Western).

Data was collected from August to October using field observation and line intersect method. In this study, one meter transects were used to count small herbs. Two meter transects were used for the tall grass and herbs. Three transect lines were used for each sampling sites. Seaweeds were collected by hand using a scraper and a stout knife. Collected seaweed was transferred in to plastic bags with sea water and labeled them for further assessment. Recommended guide books and plant identification application were used for identification and nomenclature of flora species.

Data analysis was performing using Microsoft Excel and some statistical tools. Plant diversity in the three study sites of the study area was calculated using Shannon-Wiener diversity index [14] as below, 


$$
H=-\sum_{i=1}^{S} p_{i}\left(\ln p_{i}\right)
$$

where,

$H=$ the Shannon wiener diversity index.

$p_{i}=$ fraction of the entire population made up of species $i$. ( $p_{i}$ is the proportion $(n / N)$ of individuals of the one particular species found $(n)$ divided by the total number of individuals found $(N)$.

$S=$ Number of species encountered.

Species richness of the three study sites calculated using Menhinick's index,

$$
D=S / \sqrt{N}
$$

where, " $S$ " is the number of different species represented in the sample. " $N$ " is the total number of individual organisms in the sample.

Species evenness was calculated as below, Shannon equitability is taken as a measurement of species evenness [15].

$$
\text { Evenness }(E)=H / H_{\max }
$$

where, $H$ is the Shannon Wziener index and $H_{\max }$ is the $\ln (N) ; N$ is the number of species.

Species probability measured by Simpson's Diversity Index $(D)$.

$$
D=\frac{\sum n(n-1)}{N(N-1)}
$$

where, " $n$ " is number of individuals of each species. " $N$ " is total number of individuals of all species.

Diversity between sampling sites were measured using Jaccard index of similarity

$$
J=\frac{S c}{S a+S b+S c} * 100
$$

where, " $\rho$ ' is Jaccard Index of similarity. " $S c$ " is number of species common to the two samples. " $S a$ " is number of species unique to station a. " $S b$ " is number of species unique to station $\mathrm{b}[16]$.

\section{Results}

A total of 102 flora species belonging to 50 families were recorded from the study area (Figure 2 and Table 1), Crow Island Beach Park and associated coastal ecosystem was consisted of a mosaic of five major vegetation types: Herbaceous, tree, shrub, creeper, grass. Other than that marine algae was also present. From the total number of plant species $37 \%$ is tree type plants, $21 \%$ is shrub flora, $16 \%$ is creepers, $18 \%$ is herbaceous, $4 \%$ is grass vegetation type and $4 \%$ is marine algae (Figure 2).

Proportional representation of flora species according to the vegetation type at site A comprised of $32 \%$ tree type vegetation, $26 \%$ herbaceous, $21 \%$ shrub, $15 \%$ creeper and 6\% grass type (Figure 3). Proportional representation of flora at Site 


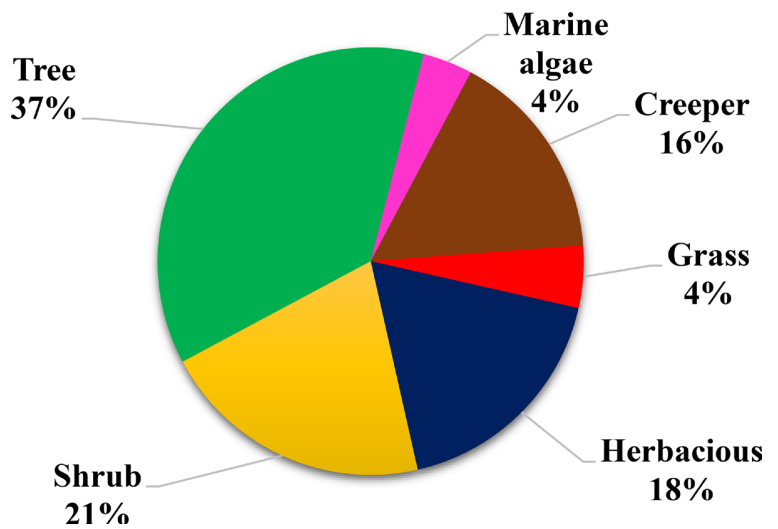

Figure 2. Proportional representation of flora species according to the vegetation type of the study area.

Table 1. Flora species composition at three study sites (site A, B and C).

\begin{tabular}{|c|c|c|c|c|c|c|c|}
\hline No & Family & Species & $\begin{array}{c}\text { Site } \\
\text { A }\end{array}$ & $\begin{array}{c}\text { Site } \\
\text { B }\end{array}$ & $\begin{array}{l}\text { Site } \\
\text { C }\end{array}$ & $\begin{array}{c}\text { Vegetation } \\
\text { type }\end{array}$ & $\begin{array}{c}\text { Medicine } \\
\text { value }\end{array}$ \\
\hline 1 & Acanthaceae & Hygrophila schulli & & + & & S & + \\
\hline 2 & Acanthaceae & Acanthus ilicifolius & & & + & $S$ & + \\
\hline 3 & Aizoaceae & Sesuvium portulacastrum & + & & & $\mathrm{H}$ & + \\
\hline 4 & Amaranthaceae & Aerva lanata & + & + & & $\mathrm{H}$ & + \\
\hline 5 & Amaranthaceae & Amaranthus spinosus & + & + & & $\mathrm{H}$ & \\
\hline 6 & Amaranthaceae & Amaranthus viridis & + & & & $\mathrm{H}$ & \\
\hline 7 & Amaranthaceae & Nothosaerva brachiata & & + & + & $\mathrm{H}$ & \\
\hline 8 & Amaranthaceae & Suaeda monoica & + & & & $S$ & \\
\hline 9 & Annonaceae & Annona glabra & + & + & + & $\mathrm{T}$ & \\
\hline 10 & Apiaceae & Centella asiatica & + & & & $\mathrm{H}$ & + \\
\hline 11 & Apocynaceae & Adenium obesum & + & & & $S$ & \\
\hline 12 & Apocynaceae & Calotropis gigantea & & + & & $S$ & + \\
\hline 13 & Apocynaceae & Cascabela thevetia & + & & & $\mathrm{T}$ & \\
\hline 14 & Apocynaceae & Catharanthus roseus & + & & & $\mathrm{H}$ & \\
\hline 15 & Apocynaceae & Cerbera odollam & + & + & + & $\mathrm{T}$ & \\
\hline 16 & Apocynaceae & Chonemorpha fragrans & + & & & $\mathrm{C}$ & \\
\hline 17 & Apocynaceae & Ichnocarpus frutescens & + & + & + & $\mathrm{C}$ & \\
\hline 18 & Araceae & Colocasia esculenta & + & & & $\mathrm{H}$ & \\
\hline 19 & Arecaceae & Cocos nucifera & + & + & & $\mathrm{T}$ & + \\
\hline 20 & Asperagaceae & Asparagus racemosus & & + & & $\mathrm{C}$ & \\
\hline 21 & Asteraceae & Eclipta prostrata & + & & + & $\mathrm{H}$ & + \\
\hline 22 & Asteraceae & Mikania cordata & & + & & $\mathrm{C}$ & + \\
\hline 23 & Asteraceae & Sphagneticola trilobata & + & & & $\mathrm{H}$ & + \\
\hline
\end{tabular}




\section{Continued}

\begin{tabular}{|c|c|c|c|c|c|c|c|}
\hline 24 & Asteraceae & Vernonia cinerea & + & + & & $\mathrm{H}$ & \\
\hline 25 & Asteraceae & Zinnia peruviana & + & & & $\mathrm{H}$ & \\
\hline 26 & Bignoniaceae & Dolichandrone spathacea & & + & + & $\mathrm{T}$ & + \\
\hline 27 & Calophyllaceae & Calophyllum inophyllum & + & + & + & $\mathrm{T}$ & + \\
\hline 28 & Capparaceae & Capparis sepiaria & & & + & $\mathrm{C}$ & \\
\hline 29 & Caricaceae & Carica papaya & + & + & & $\mathrm{T}$ & + \\
\hline 30 & Caryophyllaceae & Polycarpaea corymbosa & + & + & & $\mathrm{H}$ & \\
\hline 31 & Colchicaceae & Gloriosa superba & + & & + & $\mathrm{C}$ & \\
\hline 32 & Combretaceae & Terminalia catappa & + & + & & $\mathrm{T}$ & \\
\hline 33 & Commelinaceae & Commelina diffusa & & + & + & $\mathrm{H}$ & \\
\hline 34 & Convolvulaceae & Cuscuta chinensis & + & & & $\mathrm{C}$ & \\
\hline 35 & Convolvulaceae & Ipomoea aquatica & + & + & & $\mathrm{H}$ & \\
\hline 36 & Convolvulaceae & Ipomoea obscura & + & + & + & $S$ & \\
\hline 37 & Convolvulaceae & Ipomoea pes-caprae & + & & & $\mathrm{C}$ & + \\
\hline 38 & Convolvulaceae & Acalypha indica & + & & & $\mathrm{H}$ & \\
\hline 39 & Euphorbiaceae & Ricinus communis & & + & + & $\mathrm{T}$ & + \\
\hline 40 & Euphorbiaceae & Tragia hispida & & + & + & $\mathrm{C}$ & + \\
\hline 41 & Euphorbiaceae & Macaranga tanarius & & & + & $\mathrm{T}$ & \\
\hline 42 & Fabaceae & Acacia auriculiformis & + & + & + & $\mathrm{T}$ & \\
\hline 43 & Fabaceae & Amorpha fruticosa & + & & + & $S$ & \\
\hline 44 & Fabaceae & Caesalpinia bonducella & & + & & $\mathrm{C}$ & + \\
\hline 45 & Fabaceae & Caesalpinia pulcherrima & & & + & $\mathrm{S}$ & + \\
\hline 46 & Fabaceae & Cassia tora & + & & & $S$ & + \\
\hline 47 & Fabaceae & Crotalaria retusa & + & & & $\mathrm{S}$ & + \\
\hline 48 & Fabaceae & Cynometra iripa & & + & + & $\mathrm{T}$ & \\
\hline 49 & Fabaceae & Derris trifoliata & & + & & $\mathrm{C}$ & + \\
\hline 50 & Fabaceae & Guilandina bonduc & & + & & $S$ & + \\
\hline 51 & Fabaceae & Leucaena leucocephala & & + & & $\mathrm{T}$ & \\
\hline 52 & Fabaceae & Mimosa pudica & + & + & + & $\mathrm{H}$ & + \\
\hline 53 & Fabaceae & Pongamia pinnata & + & + & + & $\mathrm{T}$ & \\
\hline 54 & Fabaceae & Senna alata & & & + & $\mathrm{T}$ & + \\
\hline 55 & Fabaceae & Tamarindus indica & & + & & $\mathrm{T}$ & + \\
\hline 56 & Flagellariaceae & Flagellaria indica & & + & & $\mathrm{C}$ & \\
\hline 57 & Goodeniaceae & Scaevola taccada & + & + & & $S$ & + \\
\hline 58 & Hamamelidaceae & Loropetalum chinense & + & & & $S$ & \\
\hline
\end{tabular}




\section{Continued}

\begin{tabular}{|c|c|c|c|c|c|c|c|}
\hline 59 & Lamiaceae & Premna serratifolia & & + & & $S$ & + \\
\hline 60 & Lecythidaceae & Barringtonia asiatica & + & + & + & $\mathrm{T}$ & \\
\hline 61 & Lecythidaceae & Barringtonia racemosa & & + & & $\mathrm{T}$ & + \\
\hline 62 & Lythraceae & Sonneratia caseolaris & + & + & + & $\mathrm{T}$ & \\
\hline 63 & Malvaceae & Abutilon indicum & + & + & & $S$ & + \\
\hline 64 & Malvaceae & Hibiscus rosa-sinensis & + & & & $\mathrm{T}$ & \\
\hline 65 & Malvaceae & Hibiscus tiliaceus & + & + & & $\mathrm{T}$ & \\
\hline 66 & Malvaceae & Thespesia populnea & + & + & + & $\mathrm{T}$ & \\
\hline 67 & Malvaceae & Urena lobata & & & + & $S$ & \\
\hline 68 & Menispermaceae & Tinospora cordifolia & + & & + & $\mathrm{C}$ & + \\
\hline 69 & Meliaceae & Azadirachta indica & & + & & $\mathrm{T}$ & + \\
\hline 70 & Meliaceae & Swietenia mahagoni & & + & & $\mathrm{T}$ & \\
\hline 71 & Moraceae & Artocarpus camansi & & & + & $\mathrm{T}$ & + \\
\hline 72 & Moraceae & Ficus benjamina & + & & & $\mathrm{T}$ & \\
\hline 73 & Moraceae & Ficus hispida & & + & & $\mathrm{T}$ & \\
\hline 74 & Moraceae & Ficus mollis & & & + & $\mathrm{T}$ & + \\
\hline 75 & Moraceae & Ficus racemosa & + & & & $\mathrm{T}$ & + \\
\hline 76 & Muntingiaceae & Muntingia calabura & + & & & $\mathrm{T}$ & \\
\hline 77 & Musaceae & Musa balbisiana & & + & & $\mathrm{T}$ & + \\
\hline 78 & Myrtaceae & Psidium guajava & & + & & $\mathrm{T}$ & + \\
\hline 79 & Myrtales & Syzygium samarangense & & + & & $\mathrm{T}$ & \\
\hline 80 & Nyctaginaceae & Bougainvillea spectabilis & + & & & $\mathrm{C}$ & \\
\hline 81 & Oleaceae & Jasminum angustifolium & + & + & & $\mathrm{T}$ & \\
\hline 82 & Onagraceae & Circaea lutetiana & + & & & S & + \\
\hline 83 & Pandanaceae & Pandanus tectorius & + & & & $\mathrm{S}$ & + \\
\hline 84 & Passifloraceae & Passiflora foetida & + & & & $\mathrm{C}$ & + \\
\hline 85 & Plantaginaceae & Bacopa monnieri & & + & & $\mathrm{H}$ & + \\
\hline 86 & Poaceae & Aristida setacea & + & + & + & G & \\
\hline 87 & Poaceae & Cenchrus echinatus & + & & & G & \\
\hline 88 & Poaceae & Cenchrus purpureus & & + & + & G & \\
\hline 89 & Poaceae & Chrysopogon aciculatus & + & + & + & G & \\
\hline 90 & Poaceae & Poa pratensis & + & & & G & \\
\hline 91 & Portulacaceae & Portulaca grandiflora & + & & & $\mathrm{C}$ & \\
\hline 92 & Pteridaceae & Acrostichum aureum & & & + & S & + \\
\hline 93 & Rhizophoraceae & Bruguiera sp & & & + & $\mathrm{T}$ & \\
\hline
\end{tabular}




\section{Continued}

\begin{tabular}{|c|c|c|c|c|c|c|c|}
\hline 94 & Rubiaceae & Ixora coccinea & + & & & $S$ & \\
\hline 95 & Rubiaceae & Morinda citrifolia & & + & + & $\mathrm{T}$ & + \\
\hline 96 & Rubiaceae & Neolamarckia cadamba & & + & & $\mathrm{T}$ & \\
\hline 97 & Rubiaceae & Pavetta indica & & + & + & S & + \\
\hline 98 & Sapindaceae & Filicium decipiens & + & & & $\mathrm{T}$ & \\
\hline 99 & Sapotacea & Mimusops elengi & + & & & $\mathrm{T}$ & + \\
\hline 100 & Verbenaceae & Lantana camara & + & + & + & S & + \\
\hline 101 & Verbenaceae & $\begin{array}{c}\text { Stachytarpheta } \\
\text { jamaicensis }\end{array}$ & + & & & $\mathrm{H}$ & \\
\hline 102 & Vitaceae & Cissus vitiginea & & + & & C & \\
\hline
\end{tabular}

(Vegetation type: H: Herbaceous, T: Tree, S: Shrub, C: Creeper, G: Grass).

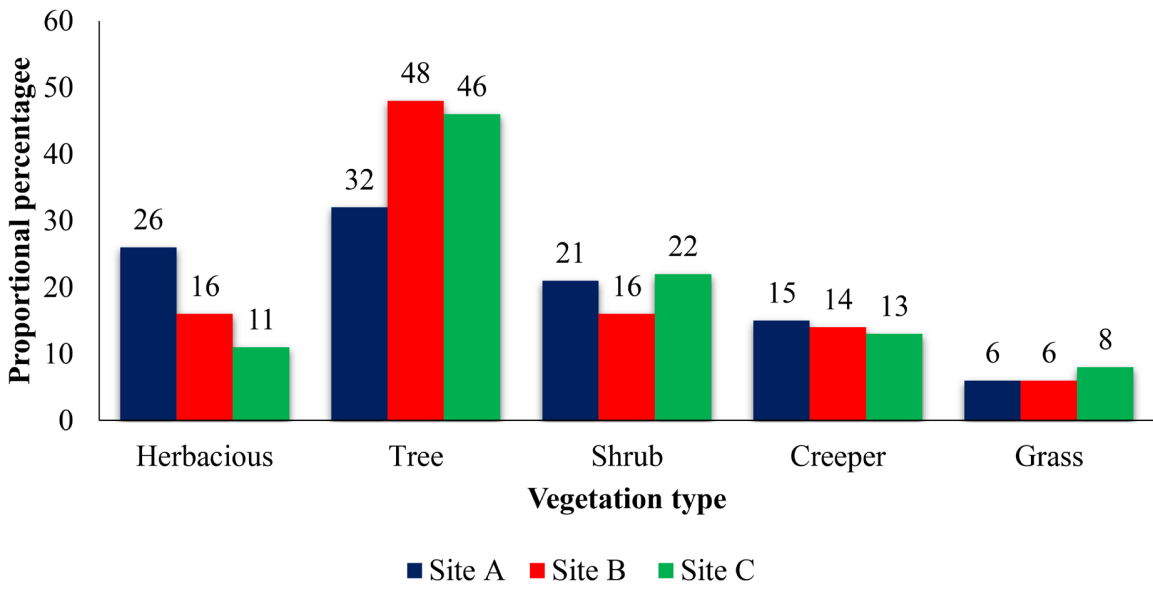

Figure 3. Proportional representation of flora species according to the vegetation type at all three sites.

B was consisted of $48 \%$ tree type vegetation, $14 \%$ creeper, $16 \%$ shrub, $16 \%$ herbaceous and $6 \%$ grass type flora species as presented in Figure 3. Flora representation for the site $\mathrm{C}$ included $46 \%$ tree types, $22 \%$ shrub, $13 \%$ creeper, $11 \%$ herbaceous and $8 \%$ grass (Figure 3). According to the Table 1, there were 46 plant species with medicinal value. From those 46 species, 16 were trees, 15 were shrubs, 8 were herbaceous and 7 were identified as creeper.

There were two true mangrove species in all three study sites namely Bruguiera sp and Sonneratia caseolaris and 16 mangrove associate species (Table 2). Sonneratia caseolaris was identified at all three study sites. While the Bruguiera sp was only found at the site $\mathrm{C}$ area. As presented in the Table 2, Mimusops elengi, Pandanus tectorius and Suaeda monoica was only found at the study site A, Whereas Calotropis gigantea was only found at the site B area, and Bruguiera sp and Acanthus ilicifolius was only found at the study site C.

The indices which are used to assess the species diversity of the study area are shown in Figure 4. The results from Table 2 revealed that the study area had a 
Table 2. No of individuals of Mangrove and Mangrove associates species recorded in site $\mathrm{A}, \mathrm{B}$ and $\mathrm{C}$.

\begin{tabular}{|c|c|c|c|c|}
\hline \multicolumn{2}{|r|}{ Species } & \multicolumn{3}{|c|}{ No of individuals } \\
\hline & & Site A & Site B & Site C \\
\hline 1 & Bruguiera sp & - & - & 1 \\
\hline 2 & Sonneratia caseolaris & 12 & 36 & 44 \\
\hline 3 & Acanthus ilicifolius & - & - & 23 \\
\hline 4 & Annona glabra & 7 & 8 & 4 \\
\hline 5 & Barringtonia asiatica & 16 & 5 & 3 \\
\hline 6 & Calophyllum inophyllum & 3 & 6 & 4 \\
\hline 7 & Calotropis gigantea & - & 7 & - \\
\hline 8 & Cerbera odollam & 24 & 7 & 3 \\
\hline 9 & Cynometra iripa & - & 4 & 2 \\
\hline 10 & Hibiscus tiliaceus & 12 & 5 & - \\
\hline 11 & Mimusops elengi & 9 & - & - \\
\hline 12 & Pandanus tectorius & 38 & - & - \\
\hline 13 & Pongamia pinnata & 5 & 16 & 8 \\
\hline 14 & Premna serratifolia & 12 & 9 & 6 \\
\hline 15 & Scaevola taccada & 13 & 4 & - \\
\hline 16 & Suaeda monoica & 4 & - & - \\
\hline 17 & Terminalia catappa & 43 & 6 & - \\
\hline 18 & Thespesia populnea & 12 & 14 & - \\
\hline
\end{tabular}

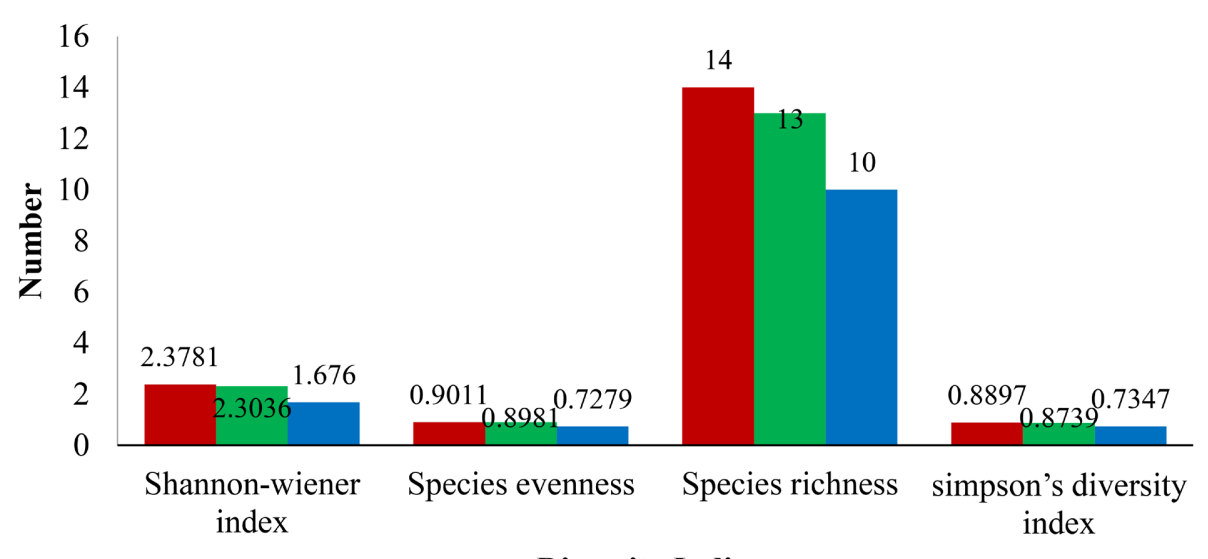

\section{Diversity Indices}

$\square$ Site A $\square$ Site B $\square$ Site C

Figure 4. Diversity indices for the Mangrove \& mangrove associates at all three study sites.

total no of 18 species with 435 individuals. The Shannon-Wiener diversity index values for the study sites were $2.378,2.303$, and 1.676 respectively. Simpson's diversity index for the study sites are $0.889,0.873$ and 0.734 correspondingly. 
Highest species richness was observed in site A while the lowest species richness was recorded at site $\mathrm{C}$ with 10 species. Species evenness for three study sites A, B and $C$ were $0.901,0.898$ and 0.728 respectively (Figure 4).

According to the study, species richness was high in all three sites (Figure 4). Species evenness and Simpson's diversity index were almost similar in all three sites. Shannon-Wiener index was less than 2 in all the three sites but it is high in the site A when compared to site C.

Jaccard index of similarity showed high values ranging from $41 \%$ to $69 \%$ between three study sites (site A, B, C) (Figure 5). In this study jaccard index registered $69 \%$ similarity between the site A and site B (Figure 5). Eleven (11) species of mangrove and mangrove associated were found common in the two study sites namely Sonneratia caseolaris, Terminalia catappa, Cerbera odollam, Pongamia pinnata, Barringtonia asiatica, Thespesia populnea, Calophyllum inophyllum, Premna serratifolia, Annona glabra, Hibiscus tiliaceus and Scaevola taccada (Table 2). Jaccard index registered $41 \%$ similarity between the site A and C (Figure 5). Seven (7) species of mangrove and mangrove associated were found common in the two study sites namely Sonneratia caseolaris, Cerbera odollam, Pongamia pinnata, Barringtonia asiatica, Calophyllum inophyllum, Premna serratifolia, Annona glabra (Table 2). Jaccard index registered 67\% similarity between the site B and C (Figure 5). Eight species (8) of mangrove and mangrove associated were found common in the two study sites namely Sonneratia caseolaris, Cerbera odollam, Pongamia pinnata, Barringtonia asiatica, Calophyllum inophyllum, Premna obtusifolia, Annona glabra, Cynometra iripa (Table 2).

There were four seaweed species found near the coastal waters of Crow Island Beach Park. They were found attached to the boulders which was laid to protect the coast from erosion. They were Chaetomorpha antennina and Rhizoclonium africanum belonging to family Cladophoraceae, Ulva compressa belonging to family Ulvaceae and Grateloupia lithophila belonging to family Halymeniaceae (Figure 6). Among those four species of algae Grateloupia lithophila was observed abundantly.

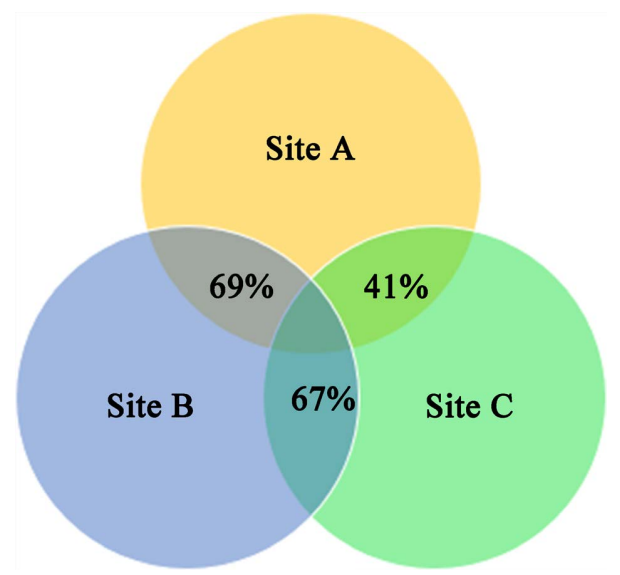

Figure 5. Jaccard index of similarity between the study sites (site A, B and C). 


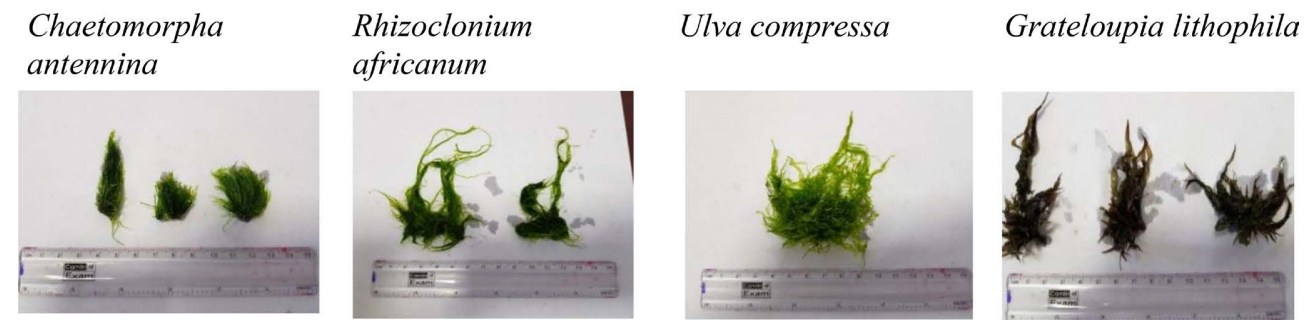

Figure 6. Seaweed species found near coastal waters of Crow Island Beach Park.

\section{Discussion}

Functions of the wetland or any other ecosystem mainly depend on its embodied biotic and abiotic components and their interaction. These components can be described as floral composition, faunal diversity, water sources of the ecological area. These components have strong bond between each other and they act as exclusive ecological system. Most of the wetlands in and around the Colombo including Crow Island are under threaten condition. The main reasons are pollution, human intervention and disturbances. Lack of baseline data makes it more difficult to assess the actual risk of these threats. Therefore, conducting a proper scientific survey is an important and a timely requirement. This study about the floral diversity of Crow Island and associated coastal ecosystems is a systematic study, conducted to in fulfill the above-mentioned requirement.

In this research, diversity indices such as Shannon-Wiener index, Simpson's diversity index, species richness, species evenness and Jaccard index of similarity for mangrove and mangrove associated species were computed in three study sites for comparison purposes. Shannon-Wiener index were high and generally range between 1.5 and 3.5. The higher Shannon Wiener-index indicates greater species richness and evenness [16]. Therefore, these high index values clearly illustrated the high floral diversity of the study sites. But site $\mathrm{C}$ reported relatively less Shannon index value than the other two sites. On the other hand, Simpson's diversity index ranges from 0 to 1 with higher values indicating presence of dominant species [17]. A, B, C study sites were registered relatively higher values of Simpson's diversity. Pandanus tectorius dominated the site A while Sonneratia caseolaris in the site B and site C. Simpson's diversity index is said to be opposite of evenness and the value gathered of three study sites supported this. In general, the diversity indices of three study sites (site A, B, C) did not differ significantly from each other. But when considering the summary of diversity indices at site A, B, C, generally the highest values recorded at site A. Further diversity indices of site B are higher than that of site C. According to the Annual Report of NARA 2006 [18], some tree plantation programs were conducted by NARA in this site B area. "Coastal recreation Nature Park at NARA premises" was one of such project activity. Therefore Mangrove and associated mangroves were introduced time to time by NARA in this site B.

Moreover, Jaccard index of similarity showed high values ranging from $41 \%$ to $69 \%$ between three study sites (site A, B, C). The Jaccard index of similarity 
the values range from $0 \%$ to $100 \%$. The higher the percentage, the more similar the two populations [16]. Therefore the present study about an assessment of the floral diversity of Crow Island Beach Park and associated area, also detected most diverse mangrove and mangrove associated ecosystem of the area by comparing diversity indices such as Simpson's, Margalef's and Shannon-Wiener's index in three main study sites of the Crow Island area.

There are some similar studies conducted in Sri Lanka in similar ecosystems previously. A study on species composition, abundance and diversity of mangroves in selected sites in Ampara district in the east coast of Sri Lanka was carried by [19]. In this study, diversity indices for mangroves based on species richness (Margalef index), proportional abundance (Shannon Wiener index) were computed. Species dominance was estimated using Simpson index and Shannon evenness were also computed. These indices were used to explain and compare the diversity of selected mangrove ecosystems. Shannon index of each mangrove site were compared with others using Hutchesont-test.

This urban coastal wetland provide habitat, shelter, nursery ground, breeding ground for numerous faunal and floral species. According to [20], a total of 30 birds species were recorded belong to 15 orders and 24 families representing $6.09 \%$ of the birds recorded in Sri Lanka also recorded from the Crow Island Beach Park area. Furthermore acts as a barrier against adverse weather and climatic condition such as storm surges, seasonal flooding and tidal fluctuation [11]. Mangrove vegetation also act as carbon sink in the area. Another study carried out a study to find the diversity, abundance and composition of phytoplankton in coastal waters of off Crow Island Beach Park and 108 phytoplankton species were recorded during the study [21]. According to the case study conducted by Rewathy and Hafsa, 2019 [22] about Crow Island Beach Park, they were detected that the public open spaces such as wetland, mangrove forest, beaches and parks are often being target on the thought of tourism development and urban development. So it is most important to protect this urban wetland system because it is the only remnant natural landscape in this area. Other land parts of the Crow Island were depleted and fragmented as a result of urbanization, industrial extension, population growth and infrastructure development of the area. This research study covers a complete description about status of floral diversity in the area. The data from the present study can be used as baseline information for future ecological studies in the area.

\section{Conclusion}

Floral diversity of the Crow Island Beach Park and associated area revealed that this coastal wetland is rich with different kinds of vegetation including plants with the medicinal values. Other than that being the coastal wetland it is also rich with mangrove and mangrove associate plants. As this park is the only coastal park in the Colombo District with this much of floral diversity this park can be used for the educational activities for the students without going far from 
their locations. General public has an inherent right of access to the Beach Park and the beaches hence local authorities have the primary authority to develop and maintain public access to Beach Park. Not all the areas of coastal Beach Park appropriate for heavy recreational use or significant human presence since it can impede upon sensitive ecological coastal resources. Therefore it is important to protect and manage this diverse landscape for current and future generations. Proper management and conservation activities should be introduced and implemented in this area. Not only that it is important to aware coastal communities through communication and education to safeguard this area to protect and conserve flora and fauna species in this.

\section{Conflicts of Interest}

The authors declare no conflicts of interest regarding the publication of this paper.

\section{References}

[1] Gunatilleke, N., Pethiyagoda, R. and Gunatilleke, S. (2008) Biodiversity of Sri Lanka. Journal of National Science Foundation of Sri Lanka, 36, 25-62. https://doi.org/10.4038/jnsfsr.v36i0.8047

[2] Coast Conservation Department (CCD) of the Ministry of Fisheries and Aquatic Resources Sri Lanka (1997) Revised Coastal Zone Management Plan, Sri Lanka. IUCN (International Union for Conservation of Nature)-Sri Lanka, Colombo.

[3] Miththapala, S. (2013) Lagoons and Estuaries. Coastal Ecosystems Series (Vol 4). IUCN (International Union for Conservation of Nature)-Sri Lanka, Colombo, 73 p.

[4] Ranawana, K.B. (2017) Mangroves of Sri Lanka. Ecology and Conservation of Mangroves in Sri Lanka, 1, 25-28. https://www.researchgate.net/publication/322924654

[5] Macnae, W. (1969) A General Account of the Fauna and Flora of Mangrove Swamps and Forests in the Indo-West Pacific Region. Advances in Marine Biology, 6, 73 103, 104a, 104b, 105-270. https://doi.org/10.1016/S0065-2881(08)60438-1

[6] Amarasinghe, M.D. (1989) Structural and Functional properties of Mangrove Ecosystems in Puttalam Lagoon and Dutch Bay, Sri Lanka. M.Phil. Thesis, University of Peradeniya, Sri Lanka, p. 217.

[7] Pinto, L. (1986) Mangroves of Sri Lanka. Natural Resources, Energy and Science Authority of Sri Lanka, Colombo, 57 p.

[8] Edirisinghe, E.A.P.N., Ariyadasa, K.P. and Chandani, R.P.D.S. (2012) Forest Cover Assessment of Sri Lanka, the Sri Lankan Forester. Journal of Sri Lanka Forest Department, 34.

[9] Jayathissa, L.P. (2012) Present Status of Mangroves in Sri Lanka. In: Weerakoon, D.K. and Wijesundara, S., Eds., The National Red List 2012 of Sri Lanka: Conservation Status of Fauna and Flora, Ministry of Environment, Colombo, 197-199

[10] The Ramsar Convention Secretariat (2018) 18 Cities Recognized for Safeguarding Urban Wetland. https://www.ramsar.org/news/18-cities-recognized-for-safeguarding-urbanwetlands

[11] Banda, C.M.M. (1989) Coastal Changes of Crow Island and Its Environs. Department of Geography, University of Peradeniya, Sri Lanka.

[12] Kotagama, S.W. and Bambaradeniya, C. (2006) An Overview of the Wetlands of Sri 
Lanka and their Conservation Significance. IUCN Sri Lanka and the Central Environmental Authority, Colombo.

[13] Amarasekara, E.A.K.K., Jayasiri, H.B. and Amarasiri, C. (2020) A Preliminary Study on Avifaunal Diversity in the Crow Island Beach Park, Urban Coastal Wetland of Sri Lanka. 2nd Research Symposium of the Ocean University of Sri Lanka, Sri Lanka, 19 November 2020, p. 32.

[14] Magurran, A.E. (1988) Diversity Indices and Species Abundance Models. In: Ecological Diversity and Its Measurement, Springer, Dordrecht, 7-45. https://doi.org/10.1007/978-94-015-7358-0 2

[15] Magurran, A.E. (2004) Measuring Biological Diversity. Blackwell Publishing, Oxford.

[16] Napaldet, J.T. and Buot Jr., I.E. (2017) Floral Diversity Assessment of Balili River as Potential Phytoremediators. Journal of Wetland Biodiversity, 7, 17-28.

[17] Glen, S. (2017) Simpson's Diversity Index: Definition, Formula, Calculation. https://www.statisticshowto.com

[18] National Aquatic Resources Research and Development Agency (2006) Annual Report. National Aquatic Resources Research and Development Agency, Colombo.

[19] Prasanna, M.G.M., Ranawana, K. and Jayasuriya, K.M.G.G. (2019) Species Composition, Abundance and Diversity of Mangroves in Selected Sites in Ampara District in the East Coast of Sri Lanka. Ceylon Journal of science (Biological Sciences), $\mathbf{4 8}$, 169-175. https://doi.org/10.4038/cjs.v48i2.7621

[20] Amarasekara, E.A.K.K., Jayasiri, H.B. and Amarasiri, C. (2021) Avifaunal Diversity in Urban Coastal Wetland of Colombo Sri Lanka. Open Access Library Journal, 8, Article No. e7256.

[21] Rathnasri, P.A.S.A., Jayasiri, H.B. and Dahanayaka, D.D.G.L. (2020) Diversity, Abundance and Composition of Phytoplankton in Coastal Waters of off Crow Island Beach Park with Reference to Physico-Chemical Parameters. 2nd Research Symposium of Ocean University of Sri Lanka, Colombo, 19November 2020, p. 39.

[22] Rewathy, K. and Hafsa, M.N.F. (2019) The Development of Urban Open Space and Environmental Distruption: A Case Study with the Special Reference with Crow Island Beach Park, Colombo. In: Arts Research Session of South Eastern University of Sri Lanka, 18 December 2019, 344-351. 